\title{
The provenance of Eocene sandstones (Gercus Formation), Northern Iraq
}

\author{
Zaid A. Malak \\ Department of Geology \\ College of Sciences \\ University of Mosul
}

\author{
Nabil Y. Al-Banna \\ College of Petroleum \\ and Mining Engineering \\ University of Mosul
}

\author{
Majid M. Al-Mutwali \\ Department of Geology \\ College of Sciences \\ University of Mosul
}

(Received 4/ 3 /2019, Accepted 25/6/2019)

\begin{abstract}
Gercus Formation is exposed in northern Iraq. When the passive Arabian continental margin collided with the active continental margin of the Turkish and Iranian plates, a part of the source rocks of Gercus red beds were carried out from Iran and Turkey territories and deposited in the molasses trough, parallel to the suture zone of the collision, and the others were driving from the longitudinal paleo-high lying parallel to the trough basin of Gercus Formation.

The present study is based on three surface sections, Bekhme, Sarsank and Amadiya areas in Northern Iraq. Generally, the Gercus Formation consists of reddish brown to light grey, well bedded sandstones and mudstones in addition to thin beds of conglomerates. The most of sandstone particles are composed of polycrystalline and monocrystalline quartz (of metamorphic and plutonic origin), $\mathrm{K}$ and $\mathrm{Na}$ - feldspar (derived from igneous and metamorphic source rocks), and chert grains of sedimentary source. Carbonate and other rock fragments with low ratio of mica group and heavy minerals (magnetite and rutile) are present too.

The sandstones of Gercus Formation, generally contain low-moderate quantities of clay as matrix in all sections, therefore, they are texturally immature. On the other hand, the low ratio of quatrz and chert to feldspar and other components indicates to mineralogically immature sandstones. According to McBride classification, it is sublith arenite - Lithic arenite sandstone. Petrographic analysis of sandstones in Bekhme section revealed that it consist of variable amount of detritus, represented by the abundance of quartz and chert rock fragments with low content of feldspar, and at Sarsank and Amadiya sections, the Gercus sandstones are characterized by the abundant chert rock fragments with high percentage of metamorphic rock fragments. So they lay in the recycled provenance source of collision orogen.
\end{abstract}

Keywords: Provenance, Eocene Sandstone, Gercus Formation, Northern Iraq.
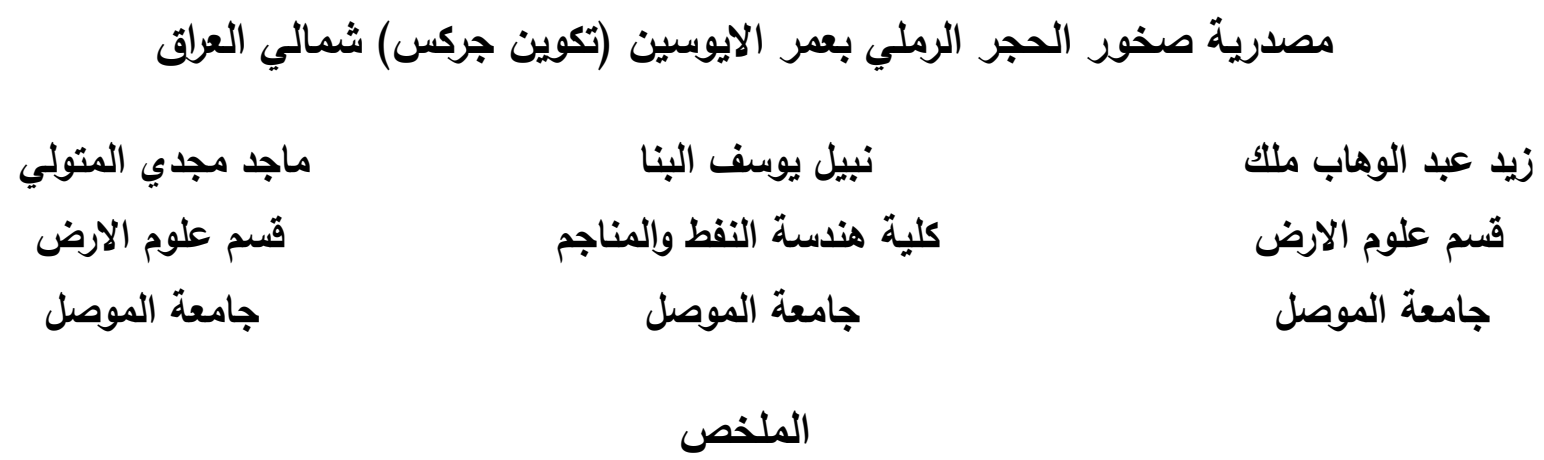
ينكثف تكوين جركس في شمالي العراق. اثتاء تصادم حافة الصفيحة العربية القارية الخاملة مع حافة الصفيح القاري التركي الايراني النشط، ولذلك فان جزءا من صخور المصدر للطبقات الحمراء لتكوين جركس التي جلبت من يابسة كل من نركيا و ايران ترسبت في خندق مولاسي كان موازيا للنطاق الدرزي لمنطقة التصادم، اما الجزء الاخر منها فقد جلبت من المناطق الناهضة القديمة بجوار الخندق ترسب فيه تكوين جركس. اعتمدت الدراسة الحالية على ثلاثة مقاطع منكثفة في كل من مناطق بخمة وسرسنك والعمادية في شمالي العراق. عموما، فان نكوين جركس يتكون من طبقات جيدة التطبق من الحجر الرملي والطيني ذي اللون البني المحمر الى الرصاصي الفاتح، اضافة الى طبقات نحيفة من المدملكات. يتألف الحجر الرملي مجهريا من معدن من فين الكوارتز الاحادي و المتعدد البلورات (ذو اصول متحولة ونارية جوفية) ومعدن الفلدسبار بنوعيه الصودي والبوتاسي ( مصدره الصخور النارية والمتحولة) وحبيبات المرو. قطع من الصخور الكاربوناتية والصخور الاخرى لهون

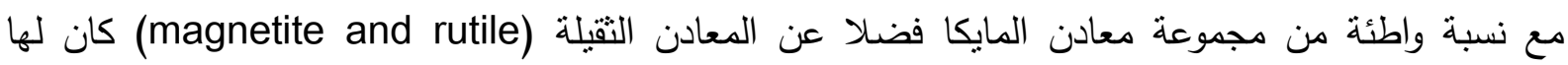
الحضور ايضا لكن بنسب واطئة. يمتاز الحجر الرملي باحتوائه على نسبة واطئة الى متوسطة من الاطبان بشكل أرضية، كما ان القيمة الواطئة لنسبة الكوارتز والجيرت مقارنة بالفلاسبار والمكونات الاخرى جعله غير ناضج نسيجيا ومعدنيا. وطبقا لتصنيف (McBride, 1963)، فان الحجر الرملي يكون من نوع الليثيك ارينايت. وطبقا للتحليل المعدني الذي تم استتاجه، فان مصدر صخور الحجر الرملي لتكوين جركس مشتق من الحزام الأوروجيني المعاد الترسيب. الكلمات الدالة: تكوين جركس، الحزام الاوروجيني، خندق، الحجر الرملي، معدن الكوارتز .

\section{INTRODUCTION}

The Gercus Formation in Iraq is comprised as red beds of clastic rocks, and it is molasse deposits of the intra Eocene Orogeny (Buday, 1980) when the Neo-Tethys ocean was finally closed and the passive Arabian continental margin collided with the active continental margins of the Turkey and Iranian plates (Numan, 1997). The continental Gercus red beds swept over from the overriding masses of Iran and Turkey, in addition to paleo high lying parallel to Gercus basin and deposited in the molasses trough, parallel to the suture zone of the collision. They extend from Mushora (NW) to Chamchamal (SW) (Jassim and Buday, 2006). The formation was first described in Southern Turkey, in Gercus region by Maxon (1936, In van Bellen et al., 1959). A supplementary type section in Iraq was given by Wetzel at Dohuk area (Jassim and Goff, 2006). The thickness of the formation in northern Iraq attained to $850 \mathrm{~m}$. It decreases to the SE and reaches to $100 \mathrm{~m}$ thick in Diyala river. The variation of thickness is affiliated to the growth of the structures in Middle Eocene time (Jassim and Buday, 2006). The fossils are very rare and probably most of them are reworked (Buday, 1980). The age of the formation has been discussed by van Bellen et al. (1959), who accept a middle Eocene age. Ameen (1998) studied Gercus Formation sedimentologically in NE-Iraq.

Al-Rawi (1980) studied the formation in Shaqlawa and Derbandikhan areas, NE Iraq and referred that the formation consists of many finning upward cycles of friable red sandstones deposited in river environment. Al-Rawi (1983) wrote about origin of 
red color in the Gercus formation. Lawa (2004) studied the formation in the Sulaimanya district concentrating on the surface contact between the Gercus Formation and the overlaying Pila Spi Formation, which appears as unconformable surface with the presence of $(1.5 \mathrm{~m})$ thick conglomerates. The lower contact of the formation with the underlaying Khurmala Formation have been studied in Duhok area by Al-Banna et al. (2006), this contact is unconformable and occurs as thick bed of conglomerates.

Al-Humaidi (2007), and Al-Qayim et al. (2008) studied the formation in AlShiekhan and Shiranish Islam areas in N- Iraq respectively, and they refer the deposition of the formation in continental-coastal environments as molasse deposits formed at the end of orogenic movements and they form the foreland basin association with the collision of the Arabian - Eurasian plates.

Five surface sections for the formation exposed in Bekhair and Aqra anticlines, northern Iraq were studied by Al-Aany (2010). From the facies analysis, mineralogical study and sieve analysis, he deduced the river, delta, sabkha and tidal flat depositional environments for the formation. Ameen (2006) wrote a detailed study about the sequence stratigraphy of Gercus Formation (Middle Eocene) in Sulaimaniya area. The aim of this study is to reconstruct the provenance of Gercus sandstones.

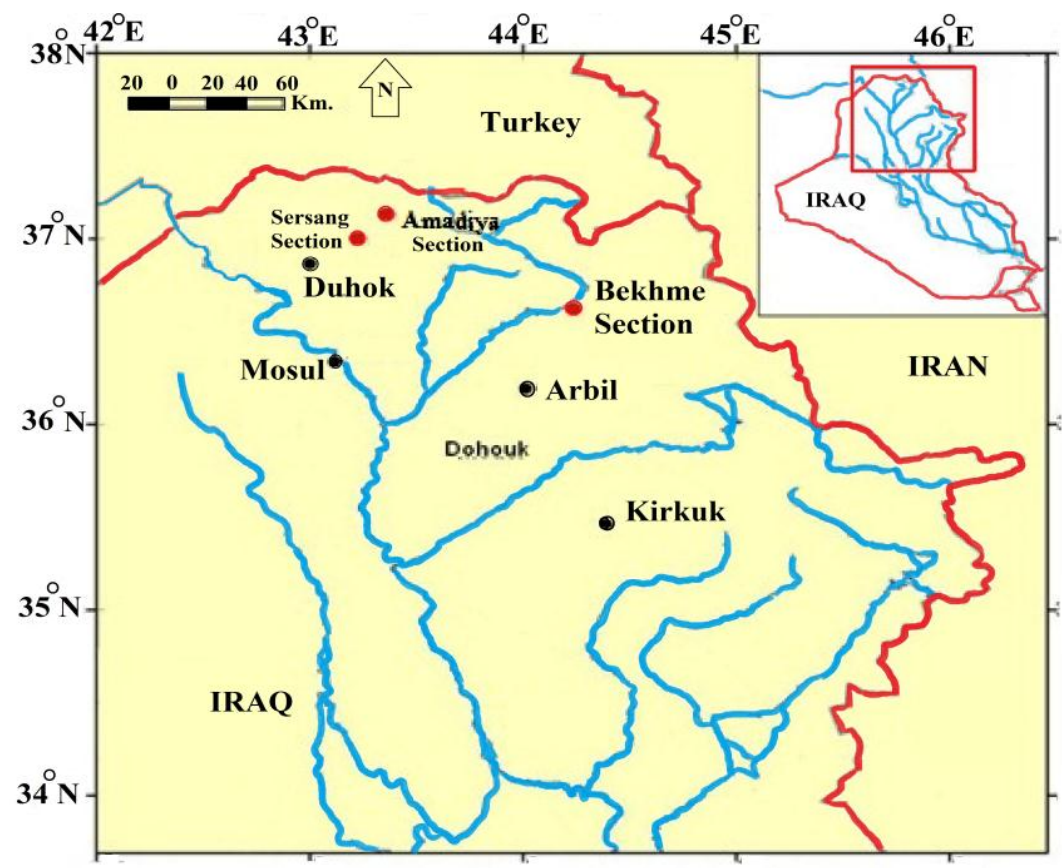

Fig. 1: Location map of the studied sections northern Iraq.

\section{GEOLOGICAL SETTING AND STRATIGRAPHY}

The present study is based on three surface sections in northern Iraq (Figure1), the first is Bekhme section (138m thick), underlined by Khurmala Formation and overlain by Pila Spi Formation. Their mid points are at $36^{\circ} 39^{\prime} 39^{\prime \prime} \mathrm{N}, 4^{\circ} 13^{\prime} 49^{\prime \prime} \mathrm{E}$.

The second is Sarsank section (74 m thick), underlined unconformably by Aqra Formation and overlain by Avanah Formation. Their mid points are at $37^{\circ} 01^{\prime} 50^{\prime \prime} \mathrm{N}$, $43^{\circ} 21^{\prime} 50^{\prime \prime} \mathrm{E}$. The third is Amadiya section (132 m thick), underlined unconformably by Aqra Formation, and overlain by Pila Spi Formation. Their mid points are at $37^{\circ}$ $06^{\prime} 25^{\prime \prime} \mathrm{N}, 43^{\circ} 29^{\prime} 23^{\prime \prime} \mathrm{E}$. 
The formation comprises brown claystones at the base, followed by friable, structureless, brown mudstones, reddish brown to grey sandy mudstones, grey - green, laminated sandstone and poorly sorted conglomerate beds at the middle and upper part of the formation. Some thin beds of carbonate are present and leaf tree is present in some intervals of the formation especially at Bekhme section (Figures 2and 3)
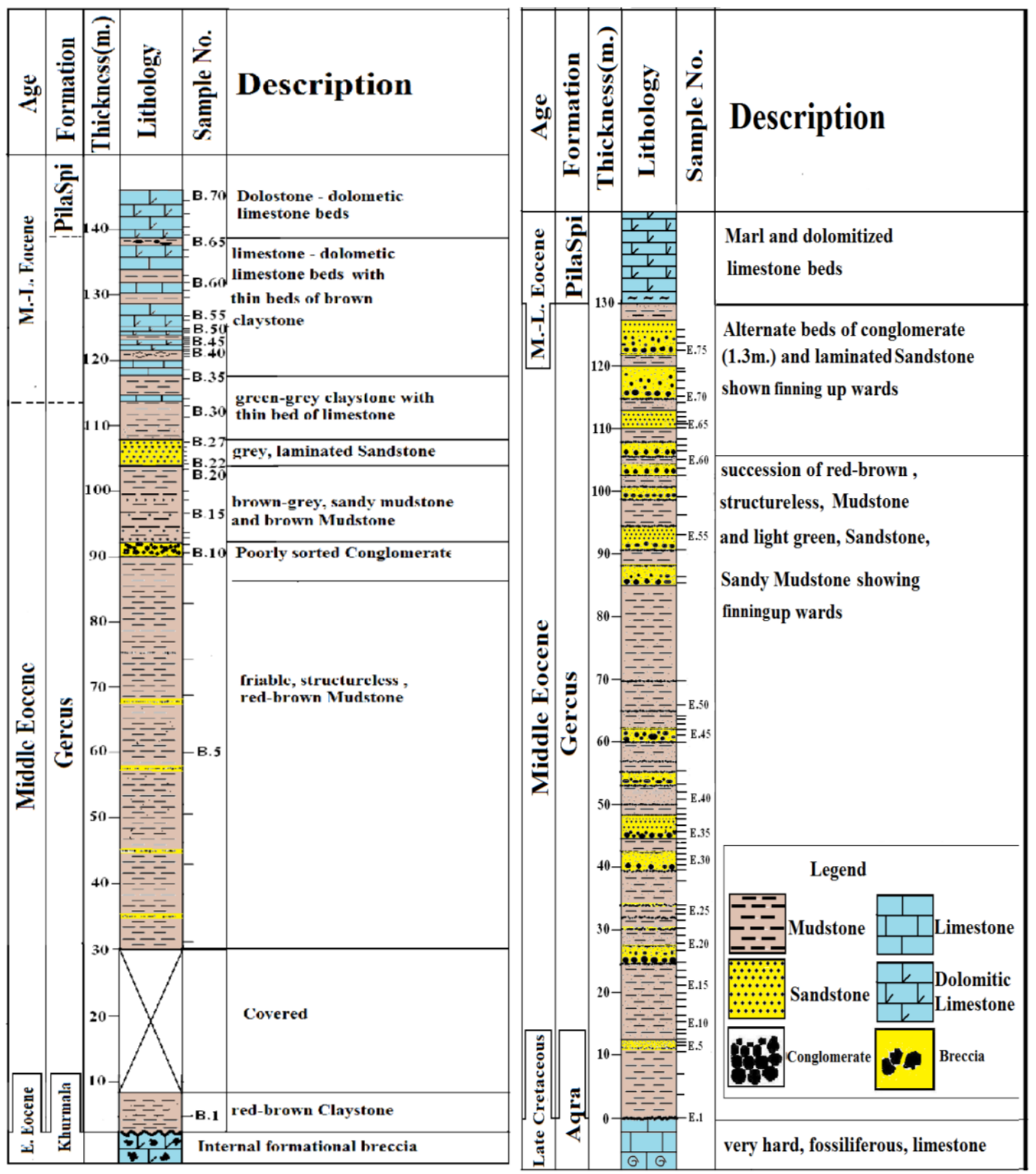

Fig, 2: Lithological sections of Gercus Formation in Bekhme (Left), and in Amadiya (Right). 


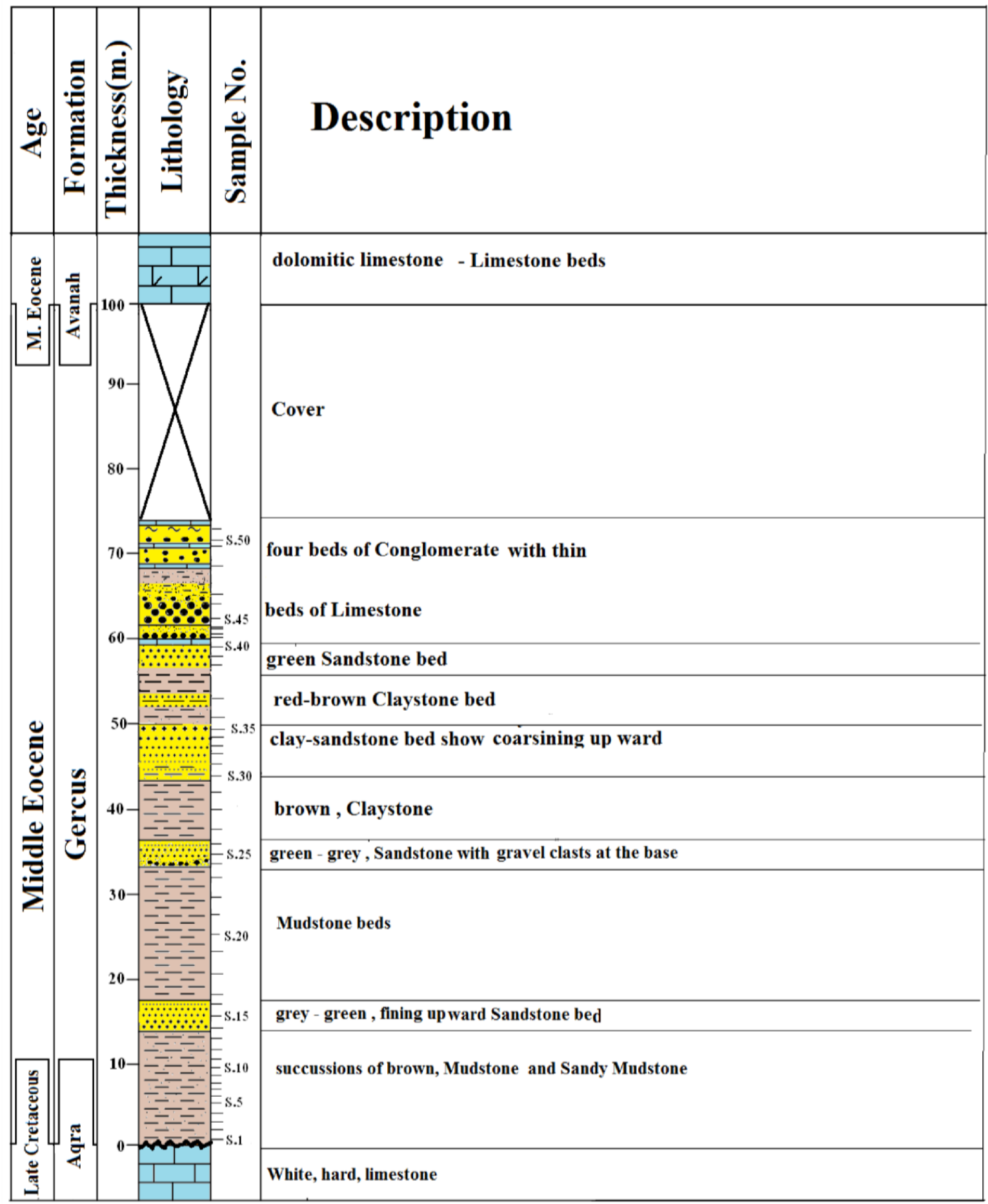

Fig. 3: Lithological section of Gercus Formation in Sarsank.

\section{MITHODOLOGY}

The petrography of sandstone was carried out using thin section description . Modal analysis of the sandstone composition was determined by point counting of an average of 300 points per thin section of a spacing of the largest grain size using GazziDickinson method (Ingorsoll et al., 1984). 


\section{RESULTS AND DISCUSSION}

The sandstone of Gercus Formation consists of quartz grains (monocrystalline (1.07-17.54\%) and polycrystalline (0.12-2.83\%), feldspar (0.11-4.22\%), and rock fragments including igneous and metamorphic (2.88-37.39\%), chert (4.27-22.51\%) and carbonate rock fragments $(0,97-21.8 \%)$. They also include clayey matrix and cementing material (mainly calcite) forming about $0.46-15.93 \%$, in addition to heavy minerals of about $2 \%$ of the total composition of the studied sandstone.

\section{Quartz:}

Quartz grains are generally monocrystalline with few polocrystalline types. Monocrystalline grains may be with or without inclusion. The common inclusions are zircon and apatite and gas vacuoles. These inclusions may occur in both metamorphic and plutonic Igneous quartz. Wavy extinction is prevalent compared with straight extinction. Quartz grain are anhedral to subhedral and sometimes angular (Figure 4a) of metamorphic and plutonic origin. Polycrystalline quartz with more than two subgrains is observed, it shows wavy extinction and suture contact (Figure 4b) which may reflect metamorphic origin (Blatt et al., 1963 and Folk, 1974).
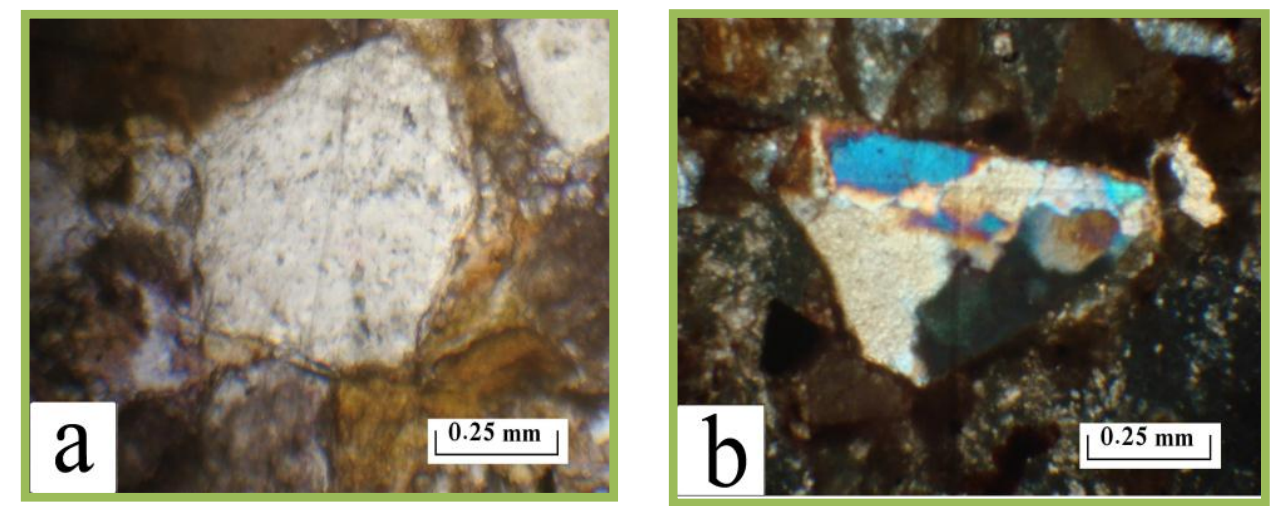

Fig. 4: a. Monocrystalline quart; b. Polycrystalline quartz.

\section{Feldspar:}

$\mathrm{K}$-feldspar and plagioclase are observed in the studied rocks. They are fresh or cloudy due to alternation to clay minerals (Tucker, 1981) figure (5a and 5b). Feldspar grains reach up to 300 microns in diameter and are usually subangular, of anhedral shape with etching edges and partially replaced by calcite. These grains are derived from igneous and metamorphic source rocks.

\section{Rock Fragments:}

Rock fragments are sedimentary (carbonate and chert) igneous and metamorphic as well. The carbonate rock fragments are abundant in Sarsank section (figure 5.c), whose percentages range between (10-54\%) and they are of less amount in Bekhme and Amadiya sections (3.92\% and $4.33 \%$ ). The source of the carbonate rock fragments is believed to be from nearby areas, probably from the underlaying Mesozoic carbonate rocks of the Arabian Shelf, which are less resistance and therefore, they can not sustain long distance of transportation. The large quantities of rock fragments in Sarsank section require high relief and rapid erosion (Pettijohn, 1975), and hence indicate tectonic uplift in the source areas, specially near Sarsank and Amadya areas. 
Chert rock fragments percentages are relatively high in Gercus sandstones (figure 5d), ranging between $9.88 \%-18.92 \%$, the grains are angular-subangular and sometimes subrounded. The source rocks should be partly the radiolarian cherts of Qulqula Series in the thrust zone and others are probably derived from the underlaying carbonate rocks that embrace cherty limestones.

The igneous and metamorphic rock fragments relatively occur in low percentages in Sarsank and Bekhme Sections, while they occur in high percentage $(20.17 \%)$ in Amadiya section. They include abundant metamorphic rock fragment represented mainly by serpentinite in addition to olivine, chlorite, rutile and magnetite. Generally, they are angular to subangular. The high percentage of serpentinites point to ultrabasic igneous source rocks, which altered to serpentinites during diagenesis.

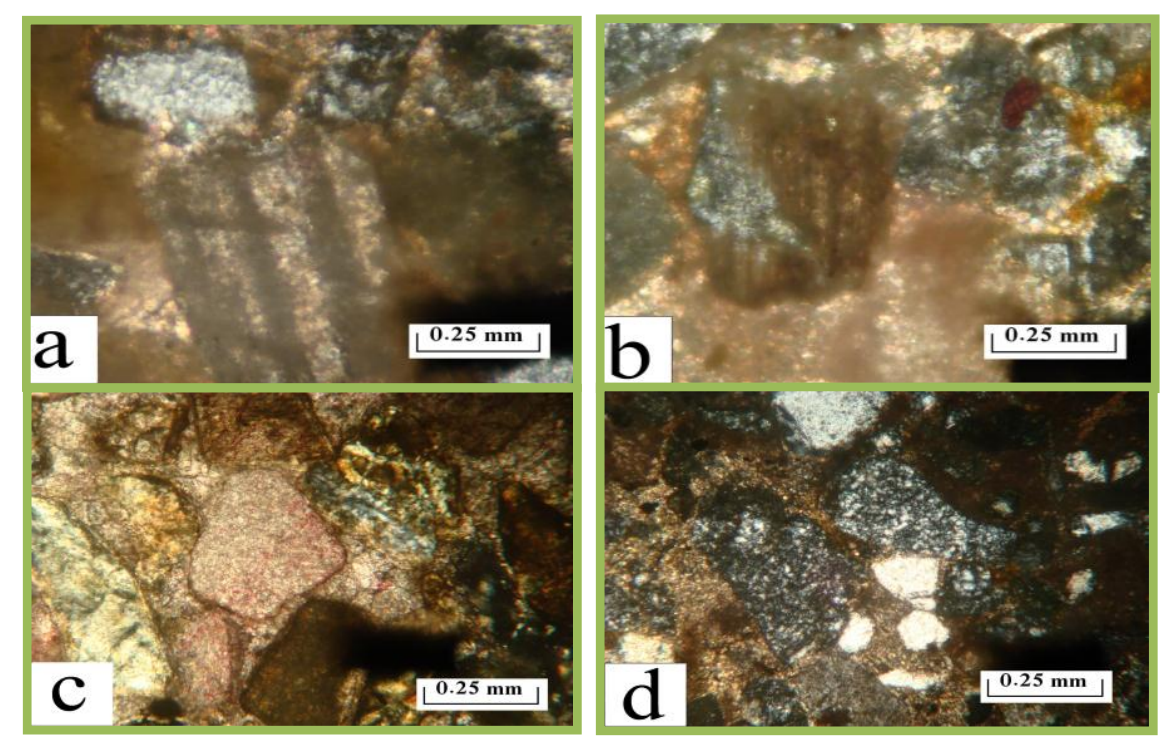

Fig. 5: a. Plagioclase mineral; b. Orthoclase mineral; c. Carbonate rock fragments; d. Chert rock fragments in Gercus sandstone.

\section{Matrix and Cements}

Carbonate cement forms the abundant type in the sandstone of the study sections, it shows high percentages in Sarsank and Amadiya sections (3.93\% and 2.82\%) respectively. Microspar and spary calcite are the main types of carbonate cement, and low percentages of iron oxide cement is recorded as well.

The sandstone of Gercus Formation contains low to moderate amounts of clay matrix in all sections. These amounts of clay matrix point to chemical weathering had been happened in the source area after unstable minerals previously present in the source area.

\section{Maturity of Sandstone}

Two types of sandstones maturity are present, physical (textural) and chemical (compositional) maturities. The degree of textural maturity depends on the relative abundance of matrix and the degree of rounding and sorting of sandstone grains (Selley, 2000). The sandstone of Gercus Formation contains clay as matrix (more than $15 \%$ ) in all sections, so this types of sandstone is texturally immature. On the other hand, the degree of chemical maturity depends on the ratio of stable grains (quartz and chert) to unstable grains (feldspar and other components) in sandstone (Boggs, 2006). This ratio is affected by weathering and transportation processes, so the unstable 
minerals had undergone destruction by these processes. According to the low quantities of quatrz and chert compared with the high quantities of feldspar and other unstable components, the sandstone of Gercus Formation is mineralogically immature.

\section{Classification of Sandstone}

Modal analysis is carried out for the sandstones of Gercus Formation using point counting of an average of 300 point per thin section using the Gazzi-Dickinson method (Ingersoll et al., 1984).

The composition of major components of sandstone (Tables 1,2 and 3) indicated that they are sub litharenite-Lithic arenite according to McBride classification (1963) of sandstone (Figure 6).

Table 1: The major petrographic constituents of Gercus sandstones in Bekhme section.

\begin{tabular}{|c|c|c|c|}
\hline S. No. & Q. \& Chert \% & F \% & R.F. \% \\
\hline B.22 & 66.7 & 7.5 & 25.8 \\
B.23 & 74.8 & 3.2 & 22.0 \\
B.24 & 72.2 & 6.5 & 21.2 \\
B.25 & 76.6 & 8.6 & 14.8 \\
B.26 & 71.0 & 9.1 & 19.9 \\
B.27 & $\mathbf{7 6 . 6}$ & $\mathbf{5 . 4}$ & $\mathbf{1 8 . 0}$ \\
\hline
\end{tabular}

Table 2: The major petrographic constituents of Gercus sandstones in Sarsank section.

\begin{tabular}{|c|c|c|c|}
\hline S. No. & Q \& Chert \% & F \% & R.F. \% \\
\hline S.37 & 20 & 4.6 & 75.4 \\
S.38 & 34.5 & 3.7 & 61.8 \\
S.39 & 35.6 & 1.1 & 63.3 \\
S.40 & 53.2 & 2.1 & 44.7 \\
S.44 & $\mathbf{4 7 . 4}$ & $\mathbf{3 . 1}$ & $\mathbf{4 9 . 5}$ \\
\hline
\end{tabular}

Table 3: The major petrographic constituents of Gercus sandstones in Amadiya section.

\begin{tabular}{|c|c|c|c|}
\hline S. No. & Q. \& Chert \% & F \% & R.F. \% \\
\hline E.52 & 32.4 & 0.3 & 67.3 \\
E.64 & 47.6 & 3 & 49.4 \\
E.68 & 44.9 & 3.3 & 51.8 \\
E.70 & 37.9 & 3.6 & 58.5 \\
E.72 & 46.9 & 0.2 & 52.9 \\
E.74 & $\mathbf{6 6 . 2}$ & $\mathbf{2 . 5}$ & $\mathbf{3 1 . 3}$ \\
\hline
\end{tabular}




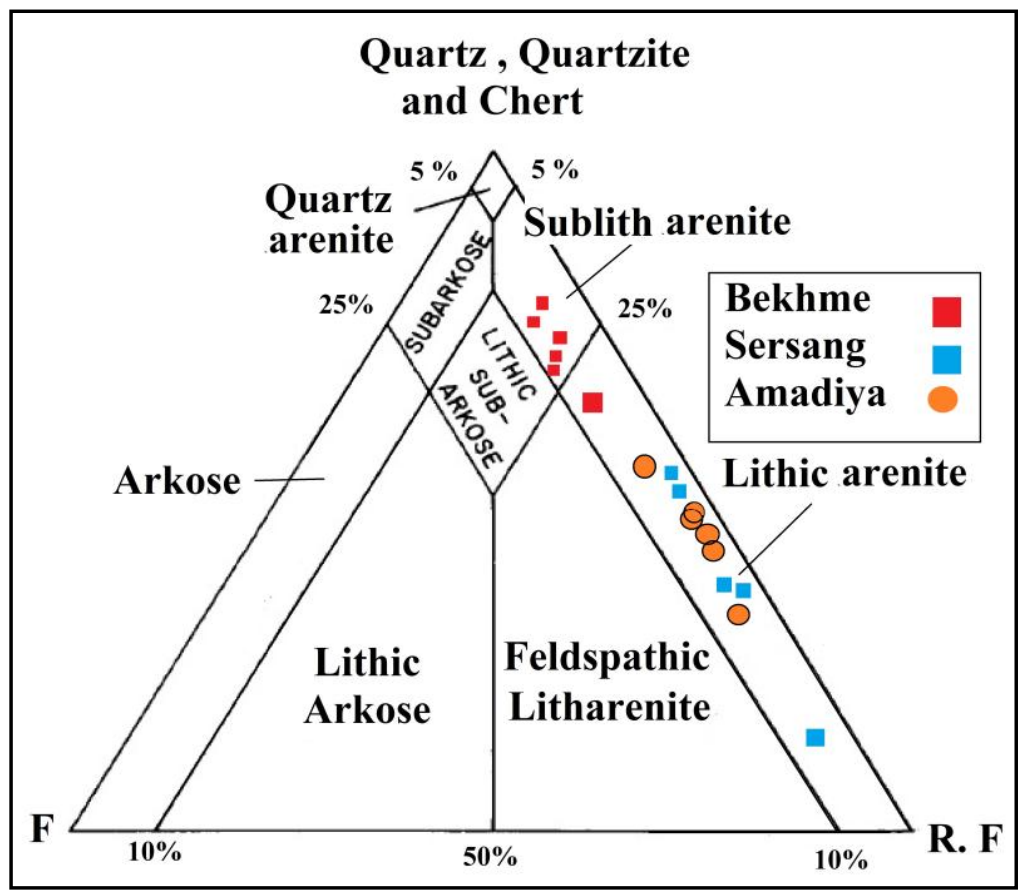

Fig. 6: Triangular Qtz. \& chert - F.- R.F. showing the type of Gercus sandstone according to McBride (1963) classification.

\section{Provenance of the studied sandstones}

As pointed out above, the sandstones petrographic data show that they contain variable amount of detritus. At Bekhme section, the sandstones of Gercus Formation are dominated by quartz and chert rock fragments with low feldspar. Whereas at Sarsank and Amadiya sections, the Gercus sandstones are characterized by abundance of chert rock fragments which increase double relative to total quartz and feldspar, in addition to high percentage of metamorphic rock fragments (serpentinite).

On the Qt-F-L and Qm-F-Lt diagrams (Figure 7 and 8) of Dickinson (1985), the Gercus sandstones plot within the field of recycled orogen and lithic recycled provenances.

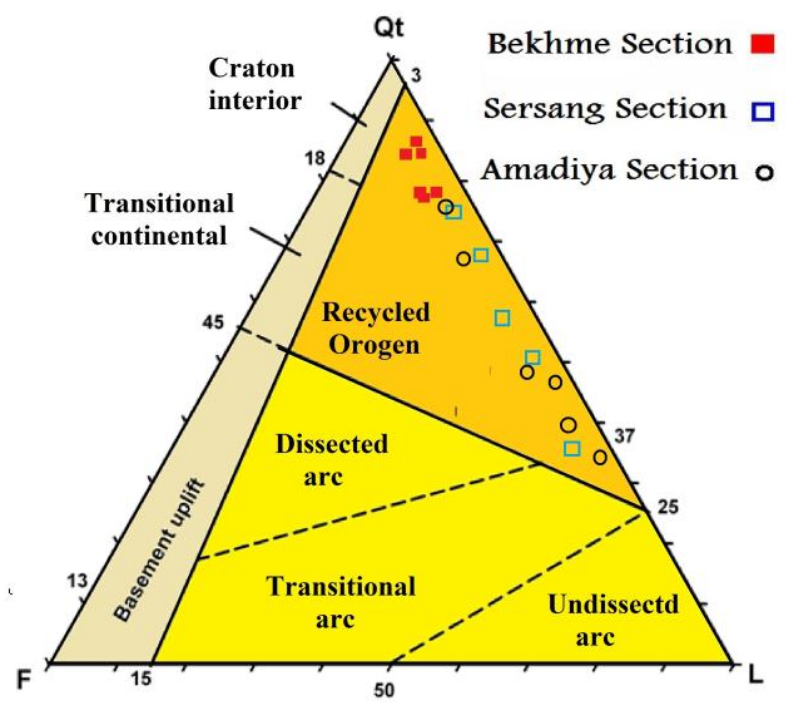

Fig. 7: Triangular (Qt-F-L) plot showing the provenance of Gercus sandstones according to Dickinson (1985). 


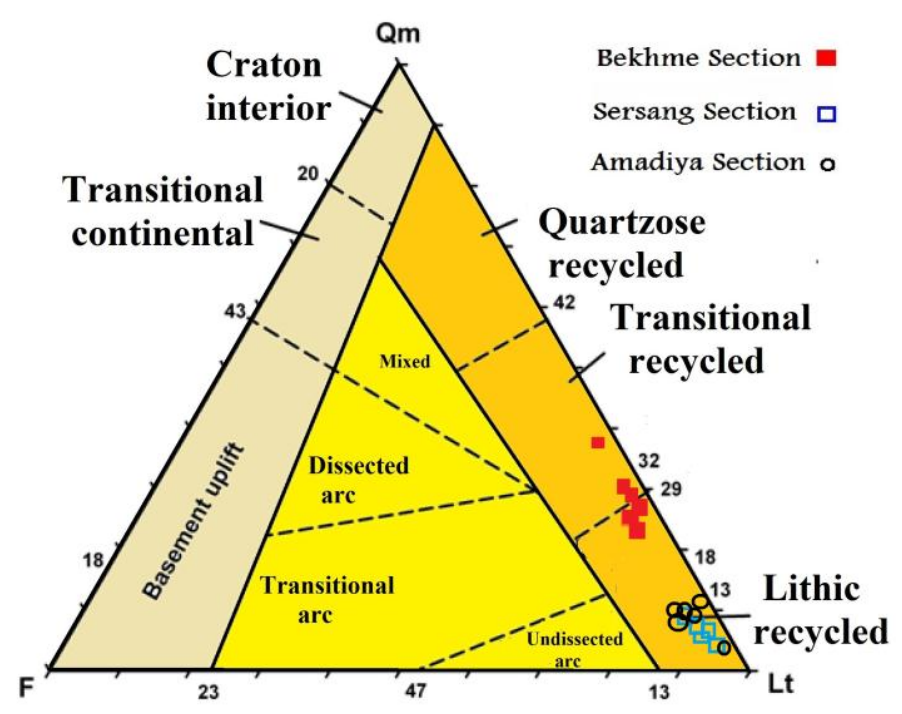

Fig. 8:Triangular Qm-F-Lt plot showing the provenance of Gercus sandstones according to Dickinson (1985).

The Igneous and metamorphic rocks exposed in orogenic belts are dominated by tectonic deformation caused by folding and thrusting processes. The output of orogenic belts activities weeps to the neighboring foreland basins (Dickinson and Suczek, 1979; Dickinson, 1985). Detecting the rock types appeared in the collision zone between Arabian Plate and Iranian and Turkish plates along the suture zone, explain the source rocks which were in conformation the Gercus sandstone. The abundance of metamorphic quartz and chert rock fragments with low feldspar content reflects the sedimentary and metamorphic origin as primary form and igneous origin as secondary form. The abundance of matrix in the sandstones refers to igneous and metamorphic origin. Consequently, the recycled orogen provenances has been proposed to the Gercus sandstones. Thereby, the source rocks of the Gercus Formation are chiefly sedimentary, igneous and metamorphic.

\section{CONCLUSIONS}

Gercus Formation consists of sandstone, mudstone and conglomerate beds. The mineral composition of sandstones are studied by point counting analysis using GazziDickinson method (Ingorsoll et al., 1984), of quartz, feldspar, chert, carbonate, metamorphic rock fragments, mica and heavy minerals. They are texturally immature, mineralogically immature too. They are classified as sub litharenite-lithic arenite according to McBride (1963). Gercus sandstones are plot in the recycled orogen provenances in Bekhme, Sarsank and Amadiya sections.

\section{REFERENCES}

Al-Aany, A. G., 2010. Facies analysis and depositional models for Gercus Formation succession in selected area, Northern Iraq. Unpublished M.Sc. Thesis, Mosul University, 151P.

Al-Banna, N. Y., Al-Mutwali, M. M. and Al-Ghrear, J. S., 2006. Facies analysis and depositional environment of Khurmala Formation in Bekhair anticline - Duhok area, North Iraq. Iraqi Jour. Earth Sci.., Vol. 6, No. 2, pp. 13-22. 
Al-Humaidi, R. I., 2007. Facies analysis and depositional environment of Late Campanian - Late Eocene successions, Sheikhan anticline, North Iraq. Unpublished Ph.D. Thesis, Mosul University, 156P.

Al-Qayim, B. A., Al-Mutwali, M. M. and Nissan, B. Y., 2008. Flysch - molasse sediments of the Paleogene foreland basin of North Iraq. Iraqi Bulletin of Geology and Mining, Vol. 4, No. 1, pp. 1 - 20.

Al Rawi, Y., 1980. Petrology and sedimentology of the Gercus Red Beds Formation (Eocene), Northeastern Iraq. Iraqi Jour. Earth Sci., Vol. 21, No. 1, pp. $132-188$.

Al-Rawi, Y., 1983. Origin of red color in the Gercus formation (Eocene) NE Iraq, J. Sedi. Geol., 35, pp. 177-192.

Ameen, B. M., 1998. Sedimentological Study of Gercus Formation in NE-Iraq Unpub.. M.Sc. thesis, Univ. of Baghdad, 103p.

Ameen, B. M., 2006. Sequence stratigraphy of Gercus Formation (Middle Eocene) In Sulaimaniya area, Northeast Iraq. Iraqi Jour. Earth Sci., Vol. 6, No.2., pp.23-32.

Bellen, R. C., Dunnington, R., Wetzel and Morton, D. M., 1959. Lexique Stratigraphique Internationale, Asie (Iraq), Fasc. 10a, Centre National de Recherche Scientifique, Paris, 333p. Reprinted in (2005) by Gulf Petrolink, Bahrain.

Boggs, S. Jr., 2006. Principles of Sedimentology and Stratigraphy. 4th ed., Pearson Prentice Hall, Upper Saddle River, New Jersey, 662 p.

Buday, T. 1980. The Regional Geology of Iraq: Stratigraphy and Paleogeography, Dar Al-Kutub Publishing House, Mosul University, 445p.

Blatt, H. and Christie, J. M., 1963. Undulatory extinction in quartz of igneous and metamorphic rocks and its significance in provenance studies of sedimentary rocks. Journal of Sedimentary Petrology. Vol. 33, pp. $559-579$.

Dickinson, W. R. and Suczek, C. A., 1979. Plate tectonics and sandstone compositions. American Association of Petroleum Geologists Bulletin, Vol. 63, No. 12 , pp. $2164-2182$.

Dickinson, W R., 1985. Interpreting provenance relations from detrital modes of sandstone, In: Zuffa, G. G., (ed.) Provenance of arenites. NATO ASI series, m Reidel Pub. Com., Dordrecht, pp. 33 - 361.

Dott, R. H., 1964. Wacke, greywacke and matrix - what approach to immature sandstone classification?. Journal of Sedimentary Petrology, Vol. 34, pp. 625 632.

Folk, R. L., 1974. Petrology of sedimentary rocks. Hemphill Pub. Comp., Taxas, 128p. Jassim, S. Z. and Buday, T., 2006. Middle Paleocene - Eocene megasequence, In: Jassim, S.Z. and Golf, J., C., 2006. Geology of Iraq. Published By Dolen, Prague and Moravian Museum, Brno., pp. 155 - 168.

Ingersoll, R. V., Bdullard, T. F., Ford, R. L., Grimm, J. P., Pickle, J. D. and Sares, S. W., 1984. The effect of grain size on detrital modes: A test of Gazzi - Dickinson point - counting method. Jour. Sed. Petrol., Vol. 45, pp. 103 -116.

Lawa, F. A. A., 2004. Sequence stratigraphic analysis of the Middle Paleocene Middle Eocene in the Sulaimani District (Kurdistan Region). Unpublished Ph.D Thesis, University of Sulaimani, $258 \mathrm{p}$

Numan, N. M., 1997. A plate tectonic scenario for the Phanerozoic succession in Iraq. Iraqi Geological Journal, Vol. 30, No. 2, pp. 85 - 110. 
Pettijhon, F. J. 1975. Sedimentary Rocks, (3rd ed). Harper and Row, New York, 628 p. Selley, R. C., 2000. Applied Sedimentology. 2nd ed, Academic Press, 521 p.

Tucker, M.E. 1981. Sedimentary Petrology, An Introduction. Vol.3, Black Well Scientific Publication. Oxford, 252p. 